\title{
Impacts of Intellectual Capital on Profitability: An Analysis on Sector Variations in Hong Kong
}

\author{
Michael C. S. Wong, Stephen C. Y. Li, Anthony C. T. Ku \\ City University of Hong Kong, Hong Kong, China
}

\begin{abstract}
With the data from blue-chip companies listed in Hong Kong, this research finds that the three components of intellectual capital, including Capital Employed Efficiency, Human Capital Efficiency, and Structural Capital Efficiency, have strong impact on profitability. However, their impacts are not equally-weighted and are not consistent in different sectors. The impact of Capital Employed efficiency is universal. However, Human Capital Efficiency appears to be more important for companies in finance sector. Structural Capital Efficiency demonstrates a very pronounced impact on companies in property sector. The results suggest that Pulic may have over simplified impacts of intellectual capital. Also, previous studies may have ignored sector variation in the impacts of intellectual capital. Future research is suggested to widen the research scope. The recommended future research areas are to study the ways to improve the management of intellectual capital; to study other factors that mostly affect the intellectual capital; and to study how the knowledge-based organizations benefited from the development of intellectual capital.
\end{abstract}

Keywords: intellectual capital, profitability, knowledge-based economy, Hong Kong Stock Exchange Listed Companies

Aim: The purpose of this study is to examine the relationship between intellectual capital and profitability as well as its impacts on companies in different sectors of Hong Kong.

Design/Methodology: Data are drawn from the companies included in the Hang Seng Composite Index, a commonly-used benchmark index for blue-chip stocks listed on Hong Kong Stock Exchange (HKSE).

Research limitations/implications: The study period covers annual reports of 2010-2013. An extended period is desirable for testing would raise the generalizability of this study. The current study only covered three years for the empirical test. It is recommended to extend the examination period to 10 to 20 years to raise the applicability of the future study.

Practical implications: The results suggest that intellectual capital is helpful to the management of the listed companies in Hong Kong.

Finding: It is observed that finance sector is efficient to leverage human capital to achieve better

Michael C. S. Wong, Ph.D., associate professor, Department of Economics and Finance, City University of Hong Kong; research fields: venture capital, financial markets, and enterprise risk management. E-mail: efmcw103@um.cityu.edu.hk.

Corresponding author: Stephen C. Y. Li, Ph.D., senior lecturer, School of Continuing \& Professional Education, City University of Hong Kong; research fields: corporate governance, corporate finance, emerging markets, international trade and finance. E-mail: cmcyli@um.cityu.edu.hk.

Anthony C. T. Ku, B.A., research assistance, School of Continuing \& Professional Education, City University of Hong Kong; research fields: corporate governance, corporate finance, and dividend policies. E-mail: cheuktungku@gmail.com. 
profitability, while properties sector and commerce and industries sector are efficient to use structural capital to enhance their profitability.

Future research is suggested to widen the research scope. The recommended future research areas are to study the ways to improve the management of intellectual capital; to study other factors that mostly affect the intellectual capital; and to study how the knowledge-based organizations benefited from the development of intellectual capital.

Intellectual capital gets increased recognition and acceptance as the prominent resources in the organizational success and new economic system (Ahangar, 2011). When modern business world highlights value creation over production efficiency, it is inevitable that the focus of the companies would also have a big change. According to Seetharaman, Sooria, and Saravanan (2002), the business world has shifted from an industrial economy to knowledge economy. In general, basic resources would include not only natural resource, capital, and labour, but also knowledge. Intellectual capital, which is an intellectual material defined by Klein and Prusak (1994) as to produce a higher valued asset by formalization, capture, and leverage. Highlighted by B. Elliott and J. Elliott (2012), the distribution of tangible assets and intangible assets in the 1980s was 70\%:30\%. However, the distribution was getting reversed to 30\%:70\% in the mid-1990s. Till now, the distribution of physical, financial assets and intangible assets is 5\%:95\% in our global world. The competition now shifts to the competitive advantages and core competences based on the management of intellectual capital.

As early as Johnson and Kaplan (1987) mentioned, intellectual capital is vital in driving the overall performance of an organization. Bornemann, Knapp, Schneider, and Sixl (1999) found that an organization which owns a better intellectual capital would achieve better performance and stronger competitive advantage than an organization which does not. Guthrie (2000) advocated that the progress of creating, capturing, and disseminating knowledge within organizations cannot be stopped. Developing intellectual capital is almost a must in knowledge-based economy to raise the competitive advantages.

It is generally expected that a company with a higher degree of effort on creating value with knowledge and innovation assets would have a higher return on assets. Most previous empirical findings suggest that the performance of a company's intellectual capital explain and improve profitability. However, there is limited study on the impacts on different sectors. Individual sectors have specific needs and competitive environments. Impacts of intellectual capital may differ among them. This research aims to examine the influence of intellectual capital on different types of companies in Hong Kong.

\section{Literature Review}

A recent study (The Management Lab 2013) pinpoints that Karl-Erik Sveiby is the first one to raise the issue of measuring intellectual capital and study how accounting practices should deal with this capital. He then published "The Invisible Balance Sheet" in 1989, proposing to measure intellectual capital by dividing into relational capital, human capital, and structural capital. This model arouses attention by many Swedish-listed companies. These companies later adopt this model for efficiency management. Furthermore, Swedish Council of Service Industries implements it as a standard recommendation on publishing annual reports. The milestone of studying intellectual capital starts from moment.

\section{The Current Change of the Economic Environment}

P. H. Jr. Sullivan and P. H. Sr. Sullivan (2000) mentioned that, as early as in the late 1990s, the business 
environment faces a dramatic change that major value of organization has been switched from tangible assets to intangible assets and that tangible assets are found to be a relatively little value to the value creation of the organizations. Guthrie and Petty (1999) suggested that the evolvement of knowledge management missions bring out two missions. First, organizations concern a continuing quest to develop a better system for creating, capturing, and disseminating knowledge. Second, there is a growing awareness that how knowledge including marketing expertise adds value to a business and even to the entirely value base.

\section{The Introduction to Intellectual Capital}

Intellectual capital, as known as a group of knowledge, is to produce a higher valued asset by formalization, capture, and leverage. It builds a higher level of competitive advantages for the companies. The key stakeholders could therefore be benefited (Klein \& Prusak, 1994; Marr, Schiuma, \& Neely, 2002). Guthrie (2000) further argued that intellectual capital is implicated in various aspects, such as economic, managerial, sociological, and technological developments. The implication is present in a manner previously unknown and largely unforeseen, but it is not emphasized in four different areas. The first area is the information society, which the intellectual capital led to the revolution in information technology. The second area is the knowledge-based economy, in which intellectual capital remarks the importance of knowledge. The third area is network society, in which intellectual capital changes patterns of interpersonal activities. The last area is organizations, in which intellectual capital gives innovation and creativity to the organizations, enhancing their competitiveness.

\section{The Components of Intellectual Capital}

Edvinsson and Malone (1997) theorized the idea of intellectual capital, arguing that intellectual capital can be split into three categories. Many previous studies, such as Starovic and Marr (2003), Chen, Cheng, and Hwang (2005), Kok (2007), Makki, Lodhi, and Rahman (2008), Ahangar (2011), Maditinos, Chatzoudes, Taairidis, and Theriou (2011), and Fathi, Farahmand, and Khorasani (2013) agree that intellectual capital comes from human capital, relational (customer) capital, and structural (organizational) capital.

Human capital refers to the knowledge, skills, and experience of the employees. Organizations lose it if the employees leave. Examples like innovation capacity, creativity, vocational qualification, work-related knowledge and competencies, proactive and reactive abilities, entrepreneurial spirit and changeability (Guthrie, 2000; Starovic \& Marr, 2003; Fathi et al., 2013). Leibowitz and Wright (1999) recommended several indicators for measuring human capital, such as the replacement and acquisition cost, generalized training and employee development cost, percentage of outsourced personnel resources, development of cross-functional team structures, and internal control and ethics.

Relational capital refers to all resources linked to the external relationships of the company, including contributions of human capital and structural capital to the relationship between the organization and its stakeholders, for instance, customer loyalty and satisfaction, company names, distribution channels, business collaborations, licensing agreements, franchising agreements, favorable contracts and negotiating capacity with financial entities (Guthrie, 2000; Starovic \& Marr, 2003; Kok, 2007). Leibowitz and Wright (1999) also suggested some indicators for measuring relational capital, such as creation and development of external relationships, brand loyalties, customer service expectations, and market share.

Structural capital refers to the non-human resources of knowledge within the organization. In other words, knowledge resources are owned by the organization. It could be classified into intellectual property and 
infrastructure asset. The former one is comprised of patents, copyrights, and trademarks. The latter one is comprised of corporate culture, financial relations, information systems, management philosophy, management processes, information systems, which is built to meet the market requirements (Guthrie, 2000; Starovic \& Marr, 2003; Kok, 2007; Fathi et al., 2013). Leibowitz and Wright (1999) argued that the indicators for measuring structural capital can be divided into process and innovation. The former one includes logistical efficiencies and administrative procedures, whereas the latter one includes renewal and development costs, change in product development and delivery cycle, adoption of industry quality standards and the organization learning capacity.

\section{The Difference Between Intellectual Capital and Intangible Asset}

However, some previous studies, such as Guthrie (2000), Kok (2007), and B. Elliott and J. Elliott (2012), argued that users always get confused about the difference between intellectual capital and intangible asset. Guthrie (2000) clarified that intangible assets refer to goodwill, whereas intellectual capital is part of the goodwill. Kok (2007) stated that intangible assets are knowledge-based items owned by the company for making future economic profit, whereas intellectual capital is knowledge-based equity that may not directly produce future economic profit.

\section{Measuring Intellectual Capital}

Pulic (1998; 2000a; 2000b) developed a convenient method in measuring intellectual capital. He believes that the market value of organizations is created by capital employed (tangible) and intellectual capital (intangible), and the latter consisting of human and structural capital.

\section{VAIC (Value Added Intellectual Coefficient) Model}

Value Added Intellectual Coefficient (VAIC) is a model that users can find out the contribution of both tangible asset (capital employed) and intangible asset (human capital and structural capital) to the value creation efficiency of the organization. The model quantifies the intellectual capital through measuring the Capital Employed Efficiency (VACA), the Human Capital Efficiency (VAHU), and the Structural Capital Efficiency (STVA). These three efficiency aspects are the components of VAIC. A higher value of VAIC means that the organization value creation has been well managed and fully utilized.

This paper follows most of the measures of VAIC model to quantify the value of intellectual capital of the selected companies in the Hang Seng Index. Many previous studies, such as Veltri (2009) and Fathi et al. (2013) advocated that the VAIC model is the most suitable and approved method for measuring intellectual capital.

This paper evaluates impacts of the three components of intellectual capital on profitability with the data of blue-chip companies listed on Hong Kong exchange. The authors find that intellectual capital exhibits strong impact on profitability. However, the impacts of the three components are not equally weighted. Capital Employed Efficiency (VACE) remains to be the key in enhancing profitability on most sectors. In finance sector, Human Capital Efficiency (VACE) enhances profitability. In both sectors of properties and commerce and industries, Structural Capital Efficiency (STVA) plays an important role.

\section{The Variables}

This section discusses the variables and their measurement in this research. The authors rely on annual reports of listed companies to compute Value Added of Company $\mathrm{i}\left(\mathrm{VA}_{\mathrm{i}}\right)$ with the following equation.

$$
V A_{i}=D P_{i}+D_{i}+I_{i}+M_{i}+R_{i}+T_{i}+W S_{i}
$$


Where:

$\mathrm{VA}_{\mathrm{i}}$ : Value added of Company $\mathrm{i}$

$\mathrm{DP}_{\mathrm{i}}$ : Depreciation expense for Company $\mathrm{i}$

$\mathrm{D}_{\mathrm{i}}$ : Dividend of Company $\mathrm{i}$

$\mathrm{I}_{\mathrm{i}}$ : Interest expense of Company $\mathrm{i}$

$\mathrm{M}_{\mathrm{i}}$ : Minority interest of Company $\mathrm{i}$

$\mathrm{R}_{\mathrm{i}}$ : Retained profit of Company $\mathrm{i}$

$\mathrm{T}_{\mathrm{i}}$ : Tax expense of Company $\mathrm{i}$

$\mathrm{WS}_{\mathrm{i}}$ : Wages and salaries of Company $\mathrm{i}$

VA indicates the total value that a company brings to its shareholders, debtholders, and employees. To generate a positive VA, the company should engage physical resources, financial resources, and intellectual capital. A company with strong intellectual capital should be able to leverage its physical resources, financial resources, human manpower, and non-physical resources. This paper focuses the following three components of intellectual capital documented by Pulic (1998) and examine their impacts on profitability:

Capital employed $\left(\mathrm{CE}_{\mathrm{i}}\right)$ : This indicates the financial resources used to support the company. The authors measure it with:

$$
C E_{i}=\text { Total Assets - Intangible Assets }
$$

Human capital $\left(\mathrm{HU}_{\mathrm{i}}\right)$ : This reflects the cost of the people involved. We measure it with

$$
H U_{i}=\text { Total expenses spent on staff and employees }
$$

Structural Capital $\left(\mathrm{ST}_{\mathrm{i}}\right)$ : This reflects non-physical infrastructure, well-established process, database, patent, trademark and copyrights used to support the operation of a company. The authors measure it with:

$$
S T i=\text { Value Added }\left(V A_{i}\right)-\text { Human Capital }\left(H U_{i}\right)
$$

Some researchers consider relational capital as a part of intellectual capital. Since this dataset does not have any reliable measure on this variable, the authors do not include it in this analysis. They believe that human capital (HU) and structural capital (ST) should have reflected the contribution of relational capital to Value Added (VA).

As CE, HU, and ST are in nominal terms, the authors transform them to be three efficiency ratios to measure their contribution to VA in individual companies. Following the practice of Pulic (1998), the authors define these efficiency ratios as follows:

$$
\begin{aligned}
& \text { Capital Employed Efficiency }\left(V A C E_{i}\right)=V A_{i} / C E_{i} \\
& \text { Human Capital Efficiency }\left(V A H U_{i}\right)=V A_{i} / H U_{i} \\
& \text { Structural Capital Efficiency }\left(S T V A_{i}\right)=S T_{i} / V A_{i}
\end{aligned}
$$

The equation on STVA equation is different from the two others, because Pulic (1998) argued that the value added from the intellectual capital on human manpower is inversely associated with that from non-physical infrastructure. When a company engages less human manpower, it may engage more non-physical infrastructure to achieve same objectives. Given the same human manpower engaged, a company that is able to engage less non-physical infrastructure will generate higher value added, which is reflected by the size of structural capital (ST). These three efficiency ratios are key measures on the components of intellectual capital in this paper. 
Pulic (1998) created a specific variable on intellectual capital known as Value-added Intellectual Capital (VAIC). He simply sums VACE, VAHU, and STVA to be the VAIC. This paper does not consider this VAIC in the analysis, because the three components of intellectual capital may have unequal contribution to total intellectual capital and thus to financial outcomes. Also, the three components of intellectual capital may have varying degree of contribution across different sectors.

Our dependent variable in this paper is profitability measured by Return on Asset $\left(\mathrm{ROA}_{\mathrm{i}}\right)$, which is a more robust measure on financial performance than Return on Equity (ROE). It is because companies may differ remarkably in their financing sources.

\section{The Model and Hypotheses}

The following figure shows the model (see Figure 1). The three components of intellectual capital should have positive impact on profitability. The aggregate impact of the three components is defined as total impact of intellectual capital.

The authors test the above conceptual model with the following regression equations. The first regression is shown below:

$$
R O A_{i}=b_{0}+b_{1} V A C E_{i}+b_{2} V A H U_{i}+b_{3} S T V A_{i}+\sum c_{j} \text { Sector }_{j}+\varepsilon
$$

Where,

$$
\text { Sector }_{j}=\text { "Properties", "Utility", and "Finance" }
$$

Our first set of hypotheses on this equation is that all the $b_{1}, b_{2}$, and $b_{3}$ should be positive. If they are positive, this means the three factors of intellectual capital have positive effects on profitability. The Sector ${ }_{j}$ of Equation 4 is a dummy variable of the jth sector, which aims to control the effect of the jth sector on the ROA. The authors consider four sectors in this analysis, namely "Properties", "Utility”, "Finance”, and "Commerce and Industries". Thus, only three sector dummies are created. The authors apply Equation 4 with the whole sample first. To mitigate bias arising from outliers of ROA, they remove the top-ten ROA and the bottom-ten ROA to be a subsample sample for re-testing the hypotheses in Equation 4.

To evaluate the relative influence of each of the intellectual capital components on ROA, they further transform ROA, VACE, VAHU, and STVA into standardized variables using the equation below:

$$
\text { Standardized } X_{i}=\left(X_{i}=\text { average } X\right) / S D(X)
$$

The standardization in Equation 5 is based on average and SD of each of the variables in the whole sample. If dependent variable and independent variables are standardized variables in a regression model, the absolute size of the coefficients can easily tell their relative influence ${ }^{1}$. After getting the standardized variables, they slightly modify Equation 4 to be Equation 6 as follows:

$$
\text { Standardized } \begin{aligned}
R O A_{i}=b_{0} & +b_{1} \text { Standardized VACE } E_{i}+b_{2} \text { Standardized VAHU } \\
& +b_{3} \text { Standardized } S T V A_{i}+\sum c_{j} \text { Sector }_{j}+\varepsilon
\end{aligned}
$$

The sector dummies are not be standardized in Equation 6. To compare the coefficients of the four sectors, we simplify Equation 4 by removing the sector dummies, namely

$$
R O A_{i}=b_{0}+b_{1} V A C E_{i}+b_{2} V A H U_{i}+b_{3} S T V A_{i}+\varepsilon
$$

Equation 7 is applied four times to deal with the four sector subsamples.

\footnotetext{
${ }^{1}$ Consider $\mathrm{y}=\mathrm{a}+\mathrm{bx}+$ error, where both $\mathrm{y}$ and $\mathrm{x}$ are standardized variables. Taking variance on both sides will yield $\operatorname{Var}(\mathrm{y})=$ $\mathrm{b}^{2} \operatorname{Var}(\mathrm{x})+\operatorname{var}($ error $)$. As $\operatorname{Var}(\mathrm{y})=\operatorname{Var}(\mathrm{x})=1, \mathrm{~b}^{2}$ will indicate how much $\operatorname{Var}(\mathrm{x})$ explaining $\operatorname{Var}(\mathrm{y})$.
} 


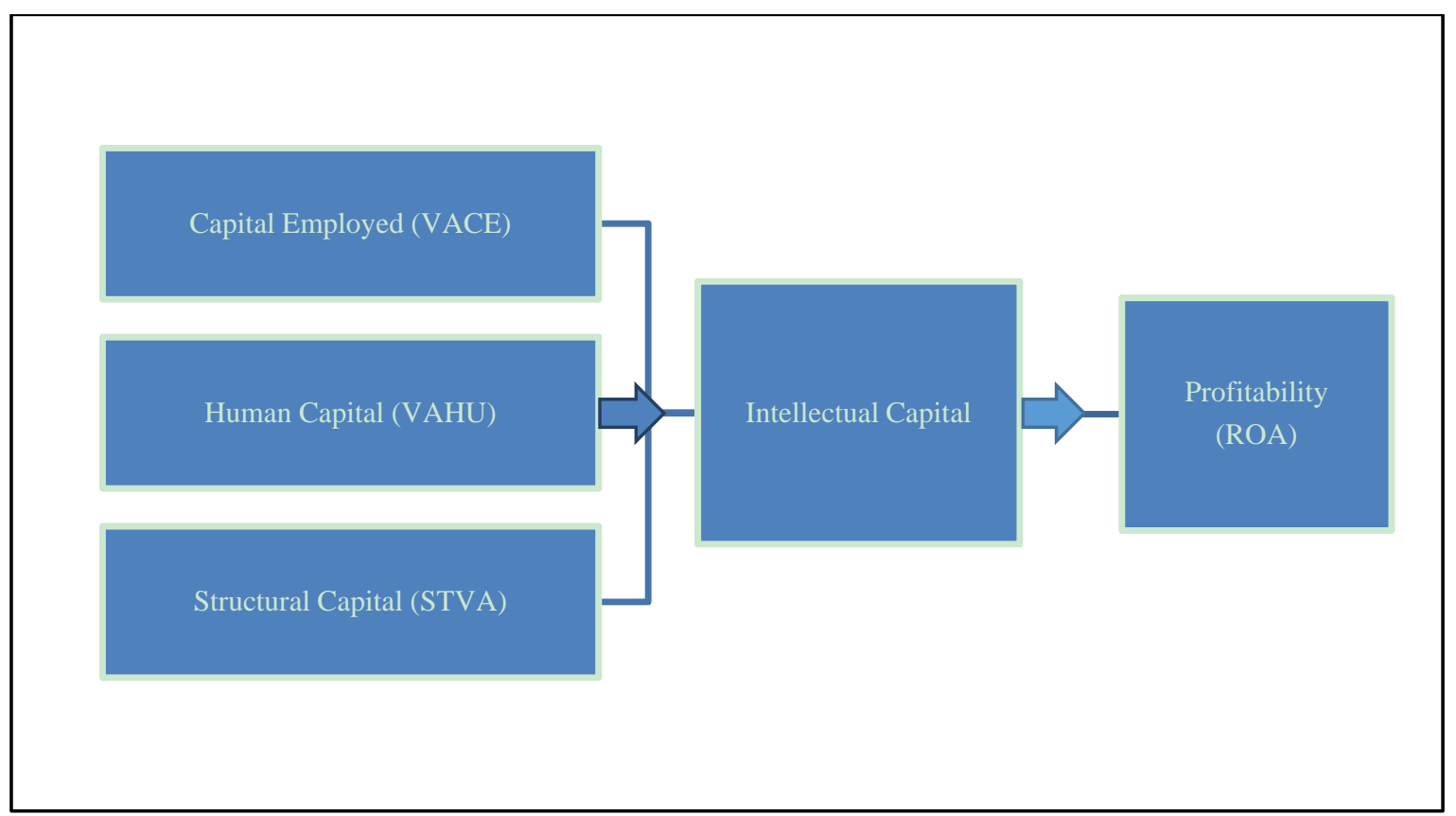

Figure 1. The model of this paper.

\section{Data and Summary Statistics}

The sample of this study includes 47 Hong Kong companies listed in the Hang Seng Index (HSI), which are classified into four sectors: commerce and industries (22 companies), finance (12 companies), properties (nine companies), and utilities (four companies). The data are extracted record the financial information of those companies during 2010-2013. All of the data are available on the websites of the companies. These selected companies are component stocks of Hang Seng Composite Index, a commonly-used benchmark index for blue-chip stocks listed on Hong Kong exchange. The total number of component stocks in the index is 50 . Since three companies do not provide the information required for this analysis, only 47 companies are included. This means the sample is very representative of sizable companies listed in Hong Kong.

Table 1 shows the names of the 47 companies. Table 2 displays the summary statistics of the whole sample and the four sectors. Table 3 shows the correlation matrix of ROA, VACE, VAHU, and STVA. The correlation statistics indicates that ROA are positively associated with the three intellectual capital factors.

Table 1

The Companies in the Whole Sample

\begin{tabular}{llll}
\hline Stock quote & Company name & Sector & $\begin{array}{l}\text { Number of } \\
\text { annual reports }\end{array}$ \\
\hline 0001 & Cheung Kong (Holdings) Ltd. & Properties & 3 \\
0002 & CLP Holdings Ltd. & Utilities & 3 \\
0003 & Hong Kong and China Gas Co. Ltd. & Utilities & 3 \\
0004 & The Wharf (Holdings) Ltd. & Properties & 3 \\
0005 & HSBC Holdings plc & Finance & 3 \\
0006 & Power Assets Holdings Ltd. & Commerce and industries & 3 \\
0011 & Hang Seng Bank Ltd. & Finance & 3 \\
0012 & Henderson Land Development Co. Ltd. & Properties & 3 \\
0013 & Hutchison Whampoa Ltd. & Commerce and industries & 3 \\
\hline
\end{tabular}


Table 1 continued

\begin{tabular}{|c|c|c|c|}
\hline Stock quote & Company name & Sector & $\begin{array}{l}\text { Number of } \\
\text { annual reports }\end{array}$ \\
\hline 0016 & Sun Hung Kai Properties Ltd. & Properties & 3 \\
\hline 0017 & New World Development Co. Ltd. & Properties & 3 \\
\hline 0019 & Swire Pacific Ltd. 'A' & Commerce and industries & 3 \\
\hline 0023 & Bank of East Asia, Ltd. & Finance & 3 \\
\hline 0027 & Galaxy Entertainment Group Ltd. & Commerce and industries & 3 \\
\hline 0066 & MTR Corporation Ltd. & Utilities & 3 \\
\hline 0083 & Sino Land Co. Ltd. & Properties & 3 \\
\hline 0101 & Hang Lung Properties Ltd. & Properties & 3 \\
\hline 0144 & China Merchants Holdings (International) Co. Ltd. & Commerce and industries & 3 \\
\hline 0267 & CITIC Pacific Ltd. & Commerce and industries & 3 \\
\hline 0291 & China Resources Enterprise, Ltd. & Commerce and industries & 3 \\
\hline 0293 & Cathay Pacific Airways Ltd. & Commerce and industries & 3 \\
\hline 0322 & Tingyi (Cayman Islands) Holdings Corp. & Commerce and industries & 3 \\
\hline 0386 & China Petroleum \& Chemical Corporation—H Shares & Commerce and industries & 3 \\
\hline 0388 & Hong Kong Exchanges and Clearing Ltd. & Finance & 3 \\
\hline 0494 & Li \& Fung Ltd. & Commerce and industries & 3 \\
\hline 0688 & China Overseas Land \& Investment Ltd. & Properties & 3 \\
\hline 0700 & Tencent Holdings Ltd. & Commerce and industries & 3 \\
\hline 0762 & China Unicom (Hong Kong) Ltd. & Commerce and industries & 3 \\
\hline 0836 & China Resources Power Holdings Co. Ltd. & Utilites & 3 \\
\hline 0857 & PetroChina Co. Ltd.-H Shares & Commerce and industries & 3 \\
\hline 0883 & CNOOC Ltd. & Commerce and industries & 3 \\
\hline 0939 & China Construction Bank Corporation-H Shares & Finance & 3 \\
\hline 0941 & China Mobile Ltd. & Commerce and industries & 3 \\
\hline 0992 & Lenovo Group Ltd. & Commerce and industries & 3 \\
\hline 1044 & Hengan International Group Co. Ltd. & Commerce and industries & 3 \\
\hline 1088 & China Shenhua Energy Co. Ltd.-H Shares & Commerce and industries & 3 \\
\hline 1109 & China Resources Land Ltd. & Properties & 3 \\
\hline 1199 & COSCO Pacific Ltd. & Commerce and industries & 3 \\
\hline 1299 & AIA Group Ltd. & Finance & 3 \\
\hline 1398 & Industrial and Commercial Bank of China Ltd.- $-\mathrm{H}$ Shares & Finance & 3 \\
\hline 1880 & Belle International Holdings Ltd. & Commerce and industries & 3 \\
\hline 1898 & China Coal Energy Co. Ltd.-H Shares & Commerce and industries & 3 \\
\hline 2318 & Ping An Insurance (Group) Co. of China Ltd.-H Shares & Finance & 3 \\
\hline 2388 & BOC Hong Kong (Holdings) Ltd. & Finance & 3 \\
\hline 2628 & China Life Insurance Co. Ltd.-H Shares & Finance & 3 \\
\hline 3328 & Bank of Communications Co., Ltd.- - H Shares & Finance & 3 \\
\hline 3988 & Bank of China Ltd.-H Shares & Finance & 3 \\
\hline
\end{tabular}

Table 2

Summary Statistics of the Whole Sample and the Four Sectors

\begin{tabular}{lllll}
\hline Panel A: whole sample & \multicolumn{5}{l}{} \\
\hline & ROA & VACE & VAHU & STVA \\
\hline Mean & 0.0628 & 0.1781 & 10.6214 & 0.8188 \\
Median & 0.0540 & 0.1600 & 7.4350 & 0.8650 \\
Standard deviation & 0.0473 & 0.1289 & 12.0844 & 0.1561 \\
Kurtosis & 0.3643 & 0.8916 & 22.4590 & 6.0313 \\
\hline
\end{tabular}


Table 2 continued

\begin{tabular}{|c|c|c|c|c|}
\hline \multicolumn{5}{|c|}{ Panel A: whole sample } \\
\hline & ROA & VACE & VAHU & STVA \\
\hline Skewness & 0.8917 & 1.0084 & 4.1577 & -2.2224 \\
\hline Range & 0.2196 & 0.6145 & 93.5860 & 0.8790 \\
\hline Minimum & 0.0052 & 0.0175 & 1.1240 & 0.1100 \\
\hline Maximum & 0.2248 & 0.6320 & 94.7100 & 0.9890 \\
\hline Count & 141 & 141 & 141 & 141 \\
\hline \multicolumn{5}{|l|}{ Panel B: properties } \\
\hline & ROA & VACE & VAHU & STVA \\
\hline Mean & 0.0759 & 0.1259 & 16.6774 & 0.9293 \\
\hline Median & 0.0786 & 0.1160 & 15.1360 & 0.9330 \\
\hline Standard deviation & 0.0307 & 0.0416 & 6.9829 & 0.0300 \\
\hline Kurtosis & -0.3112 & 3.6328 & 1.1432 & 1.3942 \\
\hline Skewness & 0.4740 & 1.3312 & 1.0838 & -1.2025 \\
\hline Minimum & 0.0325 & 0.0540 & 7.0660 & 0.8580 \\
\hline Maximum & 0.1476 & 0.2640 & 35.9650 & 0.9720 \\
\hline Count & 27 & 27 & 27 & 27 \\
\hline \multicolumn{5}{|l|}{ Panel C: utility } \\
\hline & ROA & VACE & VAHU & STVA \\
\hline Mean & 0.0565 & 0.1591 & 8.8894 & 0.8813 \\
\hline Median & 0.0616 & 0.1605 & 8.1735 & 0.8765 \\
\hline Standard deviation & 0.0190 & 0.0233 & 2.1597 & 0.0244 \\
\hline Kurtosis & -1.6250 & -1.1975 & -0.2736 & -1.3075 \\
\hline Skewness & -0.2612 & 0.1087 & 0.9718 & 0.4546 \\
\hline Minimum & 0.0264 & 0.1270 & 6.7790 & 0.8520 \\
\hline Maximum & 0.0786 & 0.1970 & 13.1500 & 0.9200 \\
\hline Count & 12 & 12 & 12 & 12 \\
\hline \multicolumn{5}{|l|}{ Panel D: finance } \\
\hline & ROA & VACE & VAHU & STVA \\
\hline Mean & 0.0181 & 0.0607 & 7.0915 & 0.8396 \\
\hline Median & 0.0117 & 0.0370 & 7.2125 & 0.8610 \\
\hline Standard deviation & 0.0216 & 0.0882 & 2.3523 & 0.0645 \\
\hline Kurtosis & 11.0388 & 15.6554 & -0.1372 & 1.6901 \\
\hline Skewness & 3.3432 & 3.7596 & 0.2483 & -1.4044 \\
\hline Minimum & 0.0052 & 0.0175 & 2.9180 & 0.6570 \\
\hline Maximum & 0.1052 & 0.4840 & 12.8600 & 0.9220 \\
\hline Count & 36 & 36 & 36 & 36 \\
\hline \multicolumn{5}{|c|}{ Panel E: commerce and industries } \\
\hline & ROA & VACE & VAHU & STVA \\
\hline Mean & 0.0829 & 0.2669 & 10.3843 & 0.7510 \\
\hline Median & 0.0691 & 0.2390 & 5.0180 & 0.8000 \\
\hline Standard deviation & 0.0504 & 0.1182 & 16.3863 & 0.1977 \\
\hline Kurtosis & -0.2313 & 0.6838 & 13.9792 & 1.9636 \\
\hline Skewness & 0.6887 & 0.8404 & 3.5731 & -1.3826 \\
\hline Minimum & 0.0059 & 0.0320 & 1.1240 & 0.1100 \\
\hline Maximum & 0.2248 & 0.6320 & 94.7100 & 0.9890 \\
\hline Count & 66 & 66 & 66 & 66 \\
\hline
\end{tabular}

Note. The above counts are based on the count of annual reports included for the 47 companies. 
Table 3

Correlation Matrix of the Variables

\begin{tabular}{lllll}
\hline & ROA & VACE & VAHU & STVA \\
\hline ROA & 1.000 & & & \\
VACE & 0.670 & 1.000 & & \\
VAHU & 0.350 & 0.071 & 1.000 & \\
STVA & 0.149 & -0.263 & 0.491 & 1.000 \\
\hline
\end{tabular}

\section{Regression Results and Discussion}

Table 4 shows the regression results under Equation 4 and Equation 6. Both "Whole sample" and "Sample with outliers removed" are based on Equation 4. All the coefficients of VACE, VAHU, and STVA are significantly positive. The size of the coefficients under these two sets of sample is very close. This means outliers on ROA having very insignificant bias on the estimation results. From the size of coefficients, the influence of the three value-added factors of intellectual capital is not equal. VACE has a much higher coefficient ( 0.2309 under "Whole sample"). VAHU has the coefficient at 0.0005 and STVA has the coefficient at 0.0759 . This does not match with the equal weight of the VAIC proposed by Pulic (1998). The control dummy "Finance" is significantly negative under the two samples. This reflects the fact that finance sector tends to have lower ROA. This makes sense because finance companies, such as banks, usually maintain high financial leverage. They may just want to achieve ROA at $1 \%$ to $3 \%$.

The results under "Sample using standardized variables" show the results under Equation 6, in which ROA and the three factors are standardized variables. In this equation, the size of the coefficients can easily tell the relative influence of each of the three factors. It is obvious that VACE has the strongest impact on the ROA (with coefficient at 0.6287 ). This implies variation of VACE explaining around $39.5 \%$ of the variations of ROA (i.e., $0.6287^{2}=39.5 \%$ ). VAHU shows the lowest impact (with the coefficient at only 0.1262 ). This means it explains only $1.6 \%$ of the ROA variations.

Table 5 reports the results under Equation 7, in which the data are separated by sectors. Sector dummies are removed. The results aim to compare the coefficients across the four sectors. Under "Utility", no coefficient is significant. This should be due to very small sample size in this sector. Small sample may make regression analysis failing to give meaningful conclusion. For the remaining three sectors, VACE consistently has significantly-positive coefficients. This indicates that the companies with higher Capital Employed Efficiency generate better profitability. In other words, the knowledge on financial management, funding and liquidity management, and credit management are keys to financial success. It is interesting that both VAHU and STVA do not have consistent sign and magnitude in the three sectors. This suggests that the VAIC of Pulic (1998) may have oversimplified the impact of the components of intellectual capital. From the significantly-positive coefficients of both VAHU and STVA, the authors observe that some companies in finance sector are able to demonstrate better Human Capital Efficiency and thus achieve better profitability. It echoes a general concept that financial services are people business. People with better training and knowledge can easily add value to companies in finance sector. Both properties sector and commerce and industries sector have positive STVA. The size of STVA in the property sector is very pronounced with the coefficient at 0.6478 . This also matches with an expectation on a good property developer which should have robust process for civil engineering and workplace safety. 
Table 4

Impacts of Intellectual Capital Factors on Profitability (With Sector Dummies as Control Variables)

\begin{tabular}{|c|c|c|c|c|c|c|}
\hline & \multicolumn{2}{|c|}{ Whole-sample } & \multicolumn{2}{|c|}{ Sample with outliers removed } & \multicolumn{2}{|c|}{ Sample using standardized variables } \\
\hline & Coeff & & Coeff & & Coeff & \\
\hline Intercept & -0.0409 & $* *$ & -0.0363 & ** & 0.1032 & \\
\hline VACE & 0.2309 & $* * *$ & 0.1825 & $* * *$ & 0.6287 & $* * *$ \\
\hline VAHU & 0.0005 & $* *$ & 0.0006 & * & 0.1262 & $* *$ \\
\hline STVA & 0.0759 & $* * *$ & 0.0757 & $* * *$ & 0.2503 & $* * *$ \\
\hline Property & 0.0089 & & 0.0063 & & 0.1884 & \\
\hline Utility & -0.0107 & & -0.0085 & & -0.2252 & \\
\hline Finance & -0.0223 & $* * *$ & -0.0220 & $* * *$ & -0.4705 & $* * *$ \\
\hline Adj RSQ & 0.6130 & & 0.5998 & & 0.6130 & \\
\hline $\mathrm{N}$ & 141 & & 121 & & 141 & \\
\hline
\end{tabular}

Notes. ROA is the dependent variable. The results of "Whole sample" and "Sample with outliers removed" are based Equation 4. "Sample with outliers removed" simple delete the top 10 and the bottom ROA cases. The results of "Sample using standardized variables" are based on Equation 6, in which ROA, VACE, VAHU, and STVA are standardized variables. Under Equation 5, the size of the coefficients of VACE, VAHU, and STVA can tell their relative influence. “***, “**”, and “*”, mean "significant at $1 \%$, $5 \%$, and $10 \%$ level respectively".

Table 5

Impacts of Intellectual Capital Factors on Profitability in the Four Sectors

\begin{tabular}{lllllll}
\hline & \multicolumn{2}{c}{ Properties } & & Utility & Finance & Commerce and industries \\
\cline { 2 - 7 } & Coeff & & Coeff & Coeff & Coeff \\
\hline Intercept & -0.5656 & $* * *$ & -0.2140 & 0.1630 & $* *$ & -0.0469 \\
VACE & 0.5573 & $* * *$ & 0.3124 & 0.0841 & $* * *$ & 0.2526 \\
VAHU & -0.0018 & $*$ & -0.0054 & 0.0119 & $* * *$ & 0.0004 \\
STVA & 0.6478 & $* * *$ & 0.3046 & -0.2795 & $* * *$ & 0.0771 \\
Adj. RSQ & 0.7219 & & -0.1497 & 0.5756 & 36 & 0.4606 \\
$\mathrm{~N}$ & 27 & & 12 & 36 & 66
\end{tabular}

Notes. ROA is the dependent variable. It is based on Equation 7, in which data are separated by sectors and sector dummies are removed. “***, ““*”, and “*” mean "significant at $1 \%, 5 \%$, and $10 \%$ level respectively”.

\section{Discussion and Conclusion}

With the data from blue-chip companies listed in Hong Kong, this research finds that the three components of intellectual capital, including Capital Employed Efficiency, Human Capital Efficiency, and Structural Capital Efficiency, have strong impact on profitability. However, their impacts are not equally-weighted and are not consistent in different sectors. The impact of Capital Employed Efficiency is universal. However, Human Capital Efficiency appears to be more important for companies in finance sector. Structural Capital Efficiency demonstrates a very pronounced impact on companies in property sector. The results suggest that Pulic (1998) may have oversimplified impacts of intellectual capital. Also, previous studies may have ignored sector variation in the impacts of intellectual capital.

\section{Limitation}

Hang Seng Composite Index only covers 50 companies. Among them, three companies are excluded due to lack of information. Therefore, the sample size is reduced to 47 companies as a proxy of the all companies in the HKSE. It is recommended to cover the whole population of all companies that listed in the 
HKSE in the future study.

The period for the sample is set for 2010-2013. An extended period is desirable for testing would raise the generalizability of this study. It is recommended to extend the examination period to 10 to 20 years to raise the applicability of the future study.

\section{Future Research}

The future research is suggested to be echoed with previous research and fill the limitation of the previous research, especially to widen the research scope. The recommended future research areas are as follow:

(1) To study the ways to improve the management of intellectual capital;

(2) To study the key components of the intellectual capital employed by the organizations that have the most influence over different sectors;

(3) To study how the knowledge-based organizations benefited from the development of intellectual capital.

\section{References}

Ahangar, R. G. (2011). The relationship between intellectual capital and financial performance: An empirical investigation in an Iranian company. African Journal of Business Management, 5(1), 88-95.

Bornemann, M., Knapp, A., Schneider, U., \& Sixl, K. I. (1999). Holistic measurement of intellectual capital. Proceedings from International Symposium: Measuring and Reporting Intellectual Capital: Experiences, Issues and Prospects. Retrieved from http://www.oecd.org/dataoecd/16/20/1947871.pdf

Chen, M. C., Cheng, S. J., \& Hwang, Y. C. (2005). An empirical investigation of the relationship between intellectual capital and firms' market value and financial performance. Journal of Intellectual Capital, 6(2), 159-176.

Edvinsson, L., \& Malone, M. S. (1997). Intellectual capital: Realizing your company's true value by finding its hidden brainpower. New York, NY: Harper Business.

Elliott, B., \& Elliott, J. (2012). Financial accounting and reporting (15th ed., pp. 512-514). England: Financial Times Prentice Hall, Pearson Education Limited.

Fathi, S., Farahmand, S., \& Khorasani, M. (2013). Impact of intellectual capital on financial performance. International Journal of Academic Research in Economics and Management Sciences, 2(1). Retrieves from http://www.hrmars.com/admin/ pics/1420.pdf

Guthrie, J. (2000). The management, measurement and the reporting of intellectual capital. Journal of Intellectual Capital, 2(1), 27-41.

Guthrie, J., \& Petty, R. (1999). Knowledge management. Company Secretary, 9(1), 38-41.

Johnson, H. T., \& Kaplan, R. S. (1987). Relevance lost: The rise and fall of management accounting. Boston: Harvard Business School Press.

Klein, D. A., \& Prusak, L. (1994). Characterising intellectual capital. Cambridge, MA: Centre for Business Innovation, Ernst and Young.

Kok, A. (2007). Intellectual capital management as part of knowledge initiatives at institutions of higher learning. The Electronic Journal of Knowledge Management, 5(2), 181-192. Retrieved from http://www.jps-dir.com/forum/uploads/13352/Kok.pdf

Leibowitz, J., \& Wright, K. (1999). Does measuring knowledge make “cents”? Expert System With Applications, 17(1), 99-103.

Maditions, D., Chatzoudes, D., Taairidis, C., \& Theriou, G. (2011). The impact of intellectual capital on firms' market value and financial performance. MIBES Transactions, 5(1). Retrieved from http://www.bs.teilar.gr/mtol/images/files/volume_5/ maditinos-chatzoudes-tsairidis-theriou.pdf

Makki, M., Lodhi, S. A., \& Rahman, R. (2008). Intellectual capital performance of Pakistani listed corporate sector. International Journal of Business and Management, 3(10), 45-51.

Marr, B., Schiuma, G., \& Neely, A. (2002). Assessing strategic knowledge assets in e-business. Int. J. Business Performance Management, 4(2-4), 279-295. Retrieved from https://www.som.cranfield.ac.uk/som/dinamic-content/research/cbp/ 2002,\%20Assessing\%20Strategic\%20Knowledge\%20Assets\%20in\%20e-business\%20\%28IJBPM,\%20Marr_Schiuma_Neel y\%29.pdf 
Pulic, A. (1998). Measuring the performance of intellectual potential in the knowledge economy. Retrieved from https://www.easuring-ip.at

Pulic, A. (2000a). VAIC-An accounting tool for IC management. International Journal of Technology Management, 20(5-7), 702-714.

Pulic, A. (2000b). MVA and VAIC analysis of randomly selected companies from FTSE 250. Retrieved from http://www.vaic-on.net/download/ftse30.pdf

Seetharman, A., Sooria, H., \& Saravanan. (2002). Intellectual capital accounting and reporting in knowledge economy. Journal of Intellectual Capital, 3(2), 128-148.

Starovic, D., \& Marr, B. (2003). Understanding corporate value: managing and reporting intellectual capital. Retrieved from http://www.cimaglobal.com/Documents/ImportedDocuments/tech_techrep_understanding_corporate_value_2003.pdf

Sullivan, P. H. Jr., \& Sullivan, P. H. Sr. (2000). Valuing intangibles companies: An intellectual capital approach. Journal of Intellectual Capital, 1(4), 328-340.

Sveiby, K. E. (2010). Methods for measuring intangible assets. Retrieved from http://www.sveiby.com/articles/ IntangibleMethods.htm

The Management Lab. (2013). Intellectual capital. Retrieved from http://www.managementlab.org/files/u2/ pdf/classic\%20innovations/Intellectual_Capital.pdf

Veltri, S. (2009). The impact of intellectual capital measurement on the financial markets: A meta-analysis approach. Electronic Journal of Corporate Finance, 3(11), 54-76. 